\title{
Enhancing Language Learning Through Modern Gadgets
}

\author{
T. Kalpana Priyadharshini and T. Krithika
}

\begin{abstract}
We are living in a world where technology is becoming more and more important every day. The word ELearning has become the most significant word among the students, teachers and in every educational environment. Emails, instant messaging, blogs and wikis have transformed the way we communicate and share information with each other. This also allows learners and teachers to gather knowledge and information. It involves some form of interactivity, which may include online interaction between the learner and their teacher. The traditional way of teaching and learning require a transformation or it should be enhanced. Integrating E-Learning into secondary educational system can, however, be a major challenge. This paper summarizes that the new technologies like Skype, You tube, twitter, blogs, mobile phone apps etc will definitely improve the proficiency of language learning and teaching.
\end{abstract}

Keywords--- E-Learning, Modern Gadgets, Enhance Language Proficiency

\section{INTRODUCTION}

$\mathrm{I}^{\mathrm{N}}$ $\mathrm{N}$ Learning and teaching, E-learning places a vital role in education industry. By coming out with advanced and modern technologies in the classroom the interaction activities are increased. The E-learners is not only extended and widened in the field of education but also in almost other field. E-learning has upgraded many ways of gathering knowledge through its technologies and gadgets.

Take for example, Today's English Language Teachers use different techniques like You tube videos, Face book postings, Mobile apps, Movie-clippings, advertisements etc. These ways of learning makes the learners to be very attentive and motivated during the class. E-learning has also changed the perspective of distance learning. The modernization of technology makes the students to be equally interactive like someone present physically.

\section{PAST TEACHING TRENDS}

Teaching a Foreign Language has evolved over the centuries. Especially, the English Language was taught as a subject rather than developing a skill. The traditional teaching methods which were used in the past ignored the development of oral proficiency of the learners. The following are the few

T. Kalpana Priyadharshini, Assistant Professor, English, Department of S\&H, Jeppiaar Engineering College, Chennai. Email:jcrkalpana@gmail.com

T. Krithika, I M.A. (English Literature), Nirmala College for women, Coimbatore.E-mail:keethu2693@gmail.com

DOI: 10.9756/BIJIEMS.7439 methods adopted in the past to teach the language which includes:

- Grammar-Translation Method

- Bilingual Method

- Direct Method

- Audio-Lingual Method

- Structural Approach

- Communicative Language Training

\section{E-LEARNING TECHNOLOGIES IN LANGUAGE TEACHING}

A wide variety of technologies that can be used by language teachers to enhance learning and teaching situations. These technologies make learning and teaching more interesting, meaningful and interactive to the learners. ELearning technologies and tools are more powerful and effective because they can bring changes and reform the traditional way of learning. Because of some new and advanced learning methods through technologies the standard of learning has been increased. This makes the students to think beyond their books and helps to build their creativity.

In today's education system, the use of technology has made compulsory in order to attain the standard. Even in learning any language the technologies places a vital role. A proper and efficient training are given to the language teachers to use these advanced gadgets. As the society is becoming more technologically advanced, the learners and teachers have to get on with the trend for the better preparation. Hence education system has introduced the electronic gadgets with impetus for integrate technology standards for real life. As we can find that learners are more exposed to the digital devices and find it interesting to learn with these devices. Using electronic gadgets engages all the learning styles with audio, video, digital cameras, security devices etc. The learners are safe and secured learning through these devices.

Some of the Effective Technologies available for Enhancing the Educational Quality of Language Teaching and Learning are as follows:

E-mail

The learners can communicate with native speakers of the foreign language using E- mail by creating an email account (g-mail, yahoo, hotmail, etc) free of cost. The learners can correspond or send their assignment to the teachers concerned and get it corrected. The teacher can also provide revisions, feedback, suggestions for the betterment of every work and send them back. 
Blogs

A blog is a personal or professional journal frequently updated for public consumption. The blogs enable uploading and linking the files which is very much suited to serve as on line personal journals for students. Pinkman (2005) indicates blogging becomes communicative and interactive when participants assume multiple roles in the writing process, as readers/reviewers who respond to other writers' posts, and as writers-readers who, returning to their own posts, react to criticism of their own posts. The readers in turn can comment on what they read, although blogs can be placed in secured environments as well.

\section{Skype}

This particular technology has audio and video functions with camera. The learners can communicate and share information with their teachers or friends who are far away. Likewise, they could communicate with the native language speakers and get their pronunciation checked to improve their oral proficiency.

\section{Mobile Phone}

Thousands and thousands of apps are available in the mobile phones which is easy to access. For example, Learners can search for new words using mobile dictionary option in the mobile phones and they can enrich their vocabulary. They can also check the spelling, usage of the specific word, pronunciation etc. Moreover, they can use Short Message Service (SMS) to send queries to their instructors and get their doubts cleared.

\section{IPods}

IPods are one of the multimedia devices which helps the users to generate, deliver, exchange texts, image, audio and video messages as per the requirement. The teachers send text messages and the learners can read and answer to them. In addition to this, the learners can record and listen to their speeches, pronunciation, poems, news, short stories, dialogues etc. Thus, the iPods supports the learners of English to enhance their listening, speaking, pronunciation, grammar, vocabulary, sentence formation and also writing.

\section{E-learning Tools}

There are three important types of E-Learning tools: (i) Curriculum Tools, (ii) Digital Library Tools and (iii) Knowledge Representation Tools. Each type of tools emphasis different parts of the process. Curriculum tools provide a systematic and standard environment to support classroom learning; their functions are particularly helpful in the initiation and selection stages. Digital library tools facilitate effective and efficient access to resources to support exploration and collection while knowledge representation tools focus on formulation and representation.

\section{A. Curriculum Tools}

Curriculum tools are widely used in high school and college of education. Materials are selected and organized to facilitate class activities. Additional tools, such as discussion forums and online quizzes, are integrated to support collaboration and evaluation. A typical commercial curriculum tool includes three integrated parts: instructional tools, administration tools, and student tools. Instructional tools include curriculum design and online quizzes with automated grading. Administration tools include file management authentication, and authorization. Student tool functions include:

- Browsing class material: readings, assignments, projects, other resources

- Collaboration and sharing: asynchronous and synchronous bulletin boards and discussion forums.

- Learning progress scheduling and tracking: assignment reminders and submission, personal calendars, and activity logs.

- Self-testing and evaluation: tests designed by instructors to evaluate student performance

- WebCT and Blackboard are the most popular commercial curriculum tools. A review comparing these two tools suggests that Blackboard's flexible content management and group work support [3] make it more suitable for independent and collaborative learning. WebCT's tighter structure and fully embedded support tools make it more appropriate for guided, less independent learning. In general, these tools are tailored more to support class activities than independent research or self-study. (IJACSA)

\section{B. Digital library Tool}

While curriculum tools support class functions, digital library tools focus on locating resources. These functions support the exploration and collection phases of information search. Digital library tools help users find the right information amidst a huge amount of digital material. Digital library features usually include search, browsing, and discovering special collections or exhibits. Search and browsing are used to locate resources and explore related topics. Special collections or exhibits contain organized materials representing a unique treasure for interested users.

\section{Knowledge Representation Tool}

Tool Knowledge representation tool help learners to visually review, capture, or develop knowledge. Curriculum tools rely primarily on a text-based, syllabus approach to describing course content. This approach often fails to delineate the relationship of concepts and skills covered in one course to those covered in another. It also fails to show the knowledge base that a learner will have acquired at the end of his/her course of study. A visualization tool can engage both learners and instructors in an active learning process when they construct spatial semantic displays of the knowledge, concepts, and skills that the learner possesses and acquires

\section{CONCLUSION}

Since English has turned into a global language its presence and value in the universe has expanded enormously in the past decades. We are living in the era of technological advancement. With the aid of the technological tools the students have scaled new heights in language learning. These gadgets through globalization cater to the needs of the language learners to acquire proficiency in language. These 
electronic gadgets make the students to think differently out of their books and explore the learning skills. These gadgets have made the language learning easier, involving and interesting. It is indeed a boon to experience and taste the wonder of learning and teaching.

\section{REFERENCES}

[1] Nagaraj and Geetha, "English Language Teaching Approaches, Methods, Techniques IIedition," Orient Black Swan Hyderabad, 1996

[2] R. Bracewell, A. Breuleux, T. Laferriere, J. Benoit and M. Abdous, "The emerging contribution of online resources and tools to classroom learning and teaching," 1998.

[3] W.Horton and K. Horton, E-Learning Tools and Technologies. Hoboken, NJ: Wiley Publishing, Inc, 2003.

[4] http://elearningindustry.com/learning-a-language-interactive-videos-andspaced-repetition

[5] International Journal of Advanced Computer Science and Applications, Vol. 3, No.2, Pp.51, 2012.

[6] https://technongadget.wordpress.com/ 